\title{
An Experimental Analysis of Task-based Teaching Method in Japanese Grammar Teaching
}

\author{
Yu Jie \\ Chengdu Neusoft University, Chengdu, Sichuan Province, 611844
}

Keywords: task-based approach; Japanese grammar teaching; principle of task-coherence

\begin{abstract}
In the context of global economic integration, learning minority languages to understand other countries cultures is good for taking lead in the advance of globalization. This paper makes a simple analysis of the problems existing in the teaching activities of Japanese grammar in China, and then studies the application principles of task-based teaching methods in the teaching activities of Japanese grammar. Finally, this paper analyzes the specific application strategies of task-based approach in the teaching activities of Japanese grammar in the way of experimental inquiry, aiming to provide some feasible suggestions for the people concerned in this field.
\end{abstract}

\section{Introduction}

With the development of China's national economy and the improvement of people's living standard, various circles have paid more and more attention to the application of the task-based teaching method in the teaching activities of education in China, especially in Japanese. At present, most colleges and universities in China have taken Japanese as a major language learning direction, and have studied the effective teaching methods of Japanese grammar. Therefore, how to explore the application method of task-based teaching method in the teaching of Japanese grammar is one of the key points of the teaching staff.

\section{Problems in the Teaching of Japanese Grammar}

In the advanced education stage of Japanese grammar, the Japanese teachers in most parts of our country have adopted traditional methods of teaching, which are obviously different from the development of modernization. In the teaching activities, most teachers pay more attention to the teaching content and knowledge system in the textbooks, and fail to construct a relatively reasonable and real language learning situation for students. What students learn is limited to textbooks, lack of extracurricular outreach and extension opportunities. The content of grammar teaching is also narrow, and there is a problem with students' actual development.

In the Japanese professional teaching of colleges and universities, teachers are lacking in the management skills of students. At the same time, there are fewer students who can actively participate in learning activities. Students' enthusiasm for learning is not high, and in some ways teachers have lost their motivation to teach. From the perspective of teaching mode, it can be concluded that the students' learning and mastery of Japanese grammar is not effective in practical teaching activities, which are restricted by teachers' teaching methods and classroom organizational forms. Most teachers, when organizing classroom activities, fail to make students the main body of classroom teaching activities, which severely discourages students' enthusiasm.

Most of the teaching staff engaged in Japanese professional teaching in our country have high professional quality. However, from the perspective of actual teaching activities, it can be concluded that some teachers have insufficient experience in practice teaching, which leads to the lack of competence in organizing teaching activities. For example, when the teacher explained the relevant content of "Japanese verb preparation" to the students, it was impossible to fundamentally help the students to clarify the connection and application methods between "verb preparation", "verb survival" and "verb completion", which caused that the subtle differences between grammar can not be effectively mastered. 


\section{The Application Principle of Task-based Approach in Japanese Grammar Teaching}

The principle of task-coherence is one of the most basic characteristics of task-based approach, and it is also the fundamental principle. In the process of applying task-based approach to organize teaching activities, the staff in related fields should pay attention to the consistency of the selected tasks. By choosing a teaching method that is consistent, the teacher can improve the validity of teaching activities on the base of the original. In different learning stages, the core content of the task is emphasized repeatedly, which is conducive to strengthening the impression of knowledge points in the students' minds. Thus, when the knowledge points are exposed to different situations, they can also mobilize what they have learned and deal with the problems they encounter ${ }^{[2]}$.

The task-based teaching method requires students to actively participate in the learning process, and in the process of active learning, they can improve their learning ability and learning level. For the students in Japanese grammar learning, task-based teaching methods can help them to improve their consciousness of active communication to a certain extent. By participating in the learning task, students can improve their language learning and application ability at the original learning level, so as to achieve better communication effect.

Language learning is a process of imitation, reflection and creation. Therefore, the task-based teaching method is adhering to the development principle that urges students to imitate the habitual application of language. In the process of applying task-based teaching methods, teachers need to construct a more realistic and vivid language learning situation for students, and guide students to learn and use language in real life. Students understand and reflect on the tasks assigned by teachers, thus improving their language mastery and application ability.

\section{Experimental Exploration of Task-based Approach in Japanese Grammar Teaching}

According to the analysis and discussion of the foregoing, it can be learned that there are still some problems that need to be solved in the grammar teaching of Japanese major in colleges and universities in China. At the same time, task-based approach, as a more effective teaching method, can provide a more diversified development path for Japanese study in Chinese universities. At the stage of experimental design, the teaching objectives need to be determined. According to the training program of Japanese professional talents in colleges and universities, as well as the goal of the Japanese teaching course, the improvement of language learning and application ability is the basic goal of experimental design ${ }^{[3]}$.

By means of the control group and the experimental group, this paper makes a comparative analysis of the application effect of task-based teaching method in the teaching of Japanese in colleges and universities. In the specific operation link, it is carried out through the arrangement of teaching subjects and the pre-class task teaching mode. Students are guided to actively participate in teaching activities under the guidance of teachers and curriculum learning tasks. In the pre-class task, teachers assign students to learn tasks related to the study and subject matter, and then help them understand the task order of teaching activities. Students learn by grouping, and in the study group, according to the task assigned by the teacher, the task is assigned again. Therefore, it is more scientific and efficient to use textbooks, tutoring materials, libraries and Internet channels to acquire relevant knowledge. After completing the data collection work, the students will discuss and analyze the tasks assigned by the teachers in groups, so as to achieve the goal of preparation before the high quality class. In this part, the students in the control group adopt the traditional teaching method and do not carry out the tasks assigned before class. By analyzing the effect of classroom teaching, the effectiveness of the task teaching method is judged.

Through the analysis of the actual teaching results in the experimental group and the control group, it can be concluded that the experimental group that applied the task-based teaching method and the control group that did not use the task-based teaching method have obvious differences in the class organization and the after-class test. Among them, the experimental group that applied the task-based teaching method was well prepared in the pre-class period, so the teacher did not need to re-import the teaching link in the formal beginning of the course, thus saving the classroom 
teaching time effectively. And, because of the way the students work together before the class, and the way the group works together, it explores the expanding knowledge that has to do with the content of the class, and effectively increases the enthusiasm of the class. When the teacher passed the relevant knowledge to the students, the response time required by the students was significantly reduced. While students who participated in the teaching activities in the control group did not show the above characteristics.

Therefore, the task-based teaching method has an obvious promoting effect on the Japanese grammar teaching activities in colleges and universities in China. The teaching staff who are engaged in the teaching activities of Japanese in colleges and universities can apply the task-based teaching method reasonably in their daily work. At the same time, when teachers set up more reasonable teaching situation with task-based approach, they can arouse students' enthusiasm for participation. For example, when explaining the Japanese "quantifiers" for the students, the teacher can set up the task situation of "gym opening time consultation", getting the students to work as a group of consultants and operators. In the dialogue, with a high concentration of attention, students will experience the flexible use of grammar knowledge, and finally achieve the goal of improving the learning effect.

\section{Summary}

To sum up, compared with other kinds of teaching methods, task-based teaching method has a strong sense of innovation and development potential. For the Japanese grammar teaching of the advanced education stage, the task-based approach has a strong effect on the development of the Japanese teaching activities of the universities. The teaching staff in related fields need to fully understand the development status of education work in China and the demand of the future society for Japanese professional talents, and apply this teaching method to further improve the effectiveness of teaching activities on the existing basis.

\section{References}

[1] Li Qun. “The Importance of Integrating Japanese Communicative Teaching Grammar into Dual Professional Training Programs” [J]. Japanese Education and Studies, 2017(00): 39-42.

[2] Pan Hongya, He Feng. "The Content Validity of the Japanese Professional Level 4 in the Background of the New Examination Syllabus” [J]. Contemporary Education Theory and Practice, 2013, 5(01): 156-159.

[3] Dong Jie. “Analysis on the Content Validity of the Grammar Test of Level 4 of Japanese Major in University” [J]. Japanese Study and Research, 2011(01): 121-127. 